STUDIES IN ENGLISH LITERATURE

Volume XXIII 



\title{
A QUANTITATIVE APPROACH TO
}

\author{
THE STYLE OF \\ JONATHAN SWIFT \\ by
}

LOUIS TONKO MILIC

Columbia University

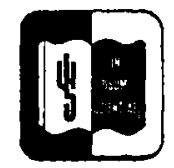

1967

MOUTON \& CO.

THE HAGUE - PARIS 
(c) Copyright 1967 by Mouton \& Co., Publishers, The Hague, The Netherlands.

No part of this book may be translated or reproduced in any form, by print, photoprint, microfilm, or any other means, without written permission from the publishers.

Printed in the Netherlands. 
To the memory of my Father 
